\title{
Learning Processes and Academic Achievement among Omani School Students
}

\author{
Marwa N. Alrajhi ${ }^{1}$, Hussain A. Alkharusi ${ }^{1}$ \& Said S. Aldhafri ${ }^{1,2}$ \\ ${ }^{1}$ Sultan Qaboos University, Muscat, The Sultanate of Oman \\ ${ }^{2}$ Research Council, Muscat, The Sultanate of Oman \\ Correspondence: Marwa N. Alrajhi, Sultan Qaboos University, Alkhoudh, P.C 123, P. O. Box 53, Oman. Tel: \\ 98-57-22-66. E-mail: malrajhi36@gmail.com
}

Received: July 14, 2016

doi:10.5539/res.v8n4p62
Accepted: August 12, $2016 \quad$ Online Published: September 29, 2016

URL: http://dx.doi.org/10.5539/res.v8n4p62

\begin{abstract}
This study examined the competing role of cognitive and affective learning processes used by students on predicting their academic achievement. The sample included 342 students from different schools in Oman (female $=74.6 \%$ ). The participants responded to a group of measures as part of a national study examining different learning variables. For the purpose of the current study, the participants' data of six measures (i.e., critical thinking strategies, organizational strategies, memory strategies, intrinsic motivation, extrinsic motivation, and anxiety) were obtained. In addition, the students' grade average point (GPA) using their reported grades were also used. The findings showed that out of the affective model, anxiety level and intrinsic motivation were significant predictors of students' academic achievement. However, critical thinking was the only predictor of academic achievement from the cognitive model.
\end{abstract}

Keywords: learning process, academic achievement, Omani students

\section{Introduction}

Apparently, one of students' concerns is how well they can do in school. Achievement is a crucial part of students' academic life and its development should be a primary goal in any school's plan. Academic achievement contributes to the way students form their self-concept (e.g., Marsh, 2004; Pinxten, Fraine, Damme, \& D'Haenens, 2013; Retelsdorf, Köller, \& Möller, 2014). Also, researchers have found significant relationships between academic achievement and different motivational constructs which may contribute to subsequent accomplishments (e.g., Roskam \& Nils, 2007; Ju, Zhang, \& Katsiyannis, 2012). A variety of factors can affect academic achievement. This paper focuses on two major types of factors which are cognitive and affective factors. Examples of cognitive factors include intelligence or cognitive ability (e.g., Beaujean et al., 2011; Steinmayr \& Spinath, 2009), cognitive styles (e.g., field-dependent vs. field independent and convergent vs. divergent thinkers) (Danili \& Reid, 2006), and cognitive processes (e.g., memorization, critical thinking and organization) (e.g., Mall-Amiri \& Sheikhy, 2014; Mouziraji \& Mouziraji, 2015; Oxford, 1990). On the other hand, examples of affective factors include motivation (e.g., Steinmayr \& Spinath, 2009), attitude (e.g., Singh,

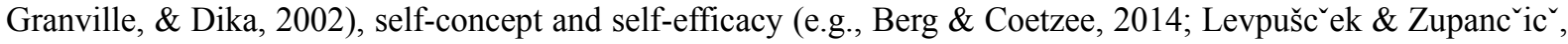
2009; Matovu, 2014).

Students simultaneously utilize both cognitive processes and affective variables to facilitate their learning. Thus, this research paper attempts to investigate the competing role of these two types of factors (i.e., cognitive processes and affective variables) on predicting students' academic achievement.

\subsection{Cognitive Processes and Affective Variables: Definition and Importance}

Learners' manipulation of both cognitive processes and affective variables is essential for learning development as each set has its distinctive properties and advantages to learning. Cognitive processes are used for understanding and producing learning outcomes; it is a "whole-brain" approach of solving problems (Oxford, 1990; Strang, 2014). Examples of cognitive processes are memorization, critical thinking, organization and elaboration (e.g., Yusri, Rahimi, Shah, \& Wah, 2013; Zusho, Pintrich, \& Coppola, 2003). On the other hand, affective variables are a way of regulating emotions while learning (Oxford, 1990). Students are able to learn how to control their emotions such as motivation or anxiety to manage developing their performance (Garcia \& 
Pintrich as cited in Ting \& Chao, 2013). Some examples of affective variables are motivation, anxiety, self-efficacy and self-concept (e.g., Deci \& Ryan, 2008; Lynch, 2006; Singh, Granville, \& Dika, 2002).

Using cognitive process and affective variables has many advantages on learning process. Some of these processes allow students to become more self-directed and autonomous learners (Lee, 2010; Oxford, 1990). Furthermore, research has shown that there is a positive relationship between the frequency of using cognitive processes and affective variables and the level of competence in different academic areas (Ansarin, Zohrabi, \& Zeynali, 2012; Ghafournia, 2014; Oxford, 1990; Ting \& Chao, 2013). Moreover, cumulative research has found positive impacts of cognitive processes and affective variables on academic achievement (e.g., Ghafournia, 2014; Strang, 2014; Ting \& Chao, 2013).

\subsection{Affective Versus Cognitive Factors and Effects on Academic Achievement}

Since the past two centuries, affective and cognitive aspects of learning have attracted much attention that led to the construction of different psychological theories and educational framework. One example of these theories is Self-Determination Theory (SDT) that dates back to the mid of 1980s (Deci \& Ryan, as cited in Rayan \& Deci, 2000). This theory exemplifies the "affective part of learning" focusing on different types of motivation such as controlled motivation and autonomous motivation as well as the effect of motivation on wellbeing and performance (Deci \& Ryan, 2008). A second example is Self-Regulatory Learning (SRL) approach that represents both affective and cognitive models of learning. It concerns one's ability to "self-monitoring" behaviors, thoughts, motivation and feelings in order to achieve a goal, either an academic or a socioemotional goal (Pintrich, 2004; Santrock, 2009). Learners are assumed to go through four main phases accompanying different strategies in each phase which are planning, monitoring, control and regulation (Pintrich, 2004). A third example is Oxford's model (1990) of learning strategies which also carefully attends to the cognitive and affective aspects of a learning process. Oxford's model encompasses six main types of learning strategies: memory, cognitive, compensation, social, affective and metacognitive strategies.

Cumulative research has studied the effect of affective variables on academic achievement. For example, Singh, Granville and Dika (2002) showed that math and science motivation and attitude significantly affect math and science achievement. Other researchers have also proved the positive contribution of motivation on academic achievement of different school subjects (e.g., Bipp \& Dam, 2014; Froiland \& Oros, 2014; Hayenga \& Corpus, 2010). Moreover, various motivational constructs, such as self-concept, self-efficacy beliefs, anxiety, value and attitude have been found to affect academic achievement (e.g., Mahyuddin et al., 2006; Seaton, Parker, Marsh, Craven, \& Yeung, 2014; Steinmayr \& Spinath, 2009; Wolters, Denton, York, \& Frances, 2014).

Similar to affective variables, the use of cognitive processes in learning was also found to influence academic achievement. The motion of cognitive psychology that stresses the importance of cognition and memory on learning has started several years ago (e.g., Little, Das, Carlson, \& Yachimowicz, 1993; Shiffrin \& Steyvers, 1997). Recently, research on cognitive processing have investigated the relationship between some cognitive processes, such as memorization, rehearsal, elaboration, organization, and critical thinking, and different academic outcomes including achievement (e.g., Aldhafri, Alkharusi, \& Al Ismaili, 2015; Areepattamannil \& Caleon, 2013; Areepattamannil, 2014a; Mall-Amiri \& Sheikhy, 2014; Strang, 2014).

\subsection{The Current Study}

The current study contributes to the literature by comparing the competing effects of three cognitive processes (memorization, organization and critical thinking) and three affective variables (extrinsic motivation, intrinsic motivation, and anxiety) on predicting Omani students' academic achievement, as well as, examining the differences within these two sets of factors. The following paragraphs demonstrate a detailed description of each process and variable and its effects on academic achievement.

Memory is defined as "the retention of information over time which involves encoding, storage and retrieval" (Santrock, 2009, p. 277). Memorization techniques include creating mental links, making associations and reviewing (Oxford, 1990). Since a long time ago, memorization has been recognized as an easy, a traditional and a reliable technique of learning that most learners depend on. For example, in mathematics, students typically tend to memorize the multiplication table to use it in further calculation processes. Researchers supported the effectiveness of memorizing multiplication table in academic performance (e.g., Djemil, 2010). Also, many researchers advocate the use of memorization in learning a foreign language (e.g., Chu, Huang, Shih, \& Tsai, 2012; Yu, 2010). However, by the beginning of $20^{\text {th }}$ century, some critiques have stood against memorization by discovering its drawbacks as a strategy of learning. Therefore, recently, memorization is recognized to have a double-edged effects since both negative (e.g., Areepattamannil \& Caleon, 2013; Areepattamannil, 2014a) and positive (e.g., Oxford, 1990; Mouziraji \& Mouziraji, 2015; Ygzaw \& Fentie, 2013) impacts of memorization on 
academic achievement have been documented in the literature. Thus, it is essential that learners do not depend solely on memorization while learning. Areepattamannil (2014a) contended that learners should have adequate "declarative knowledge" as well as "procedural" and "conditional" knowledge.

Organization is pertaining to learning techniques such as grouping, outlining, concept mapping and differentiating ideas (Keng, 1996; Lynch, 2006). Ygzaw and Fentie (2013) suggested that learners who cognitively use organization techniques in their learning are more likely to score higher in reading tests. Organization techniques differ in their usage and influence on learning. For instance, Keng (1996) found that students who used concept mapping scored higher on their written test than those who used outlining and note-taking. The author concluded that using concept mapping as a learning strategy can contribute in making meaningful learning. Other researchers found positive influences of organizational techniques while lectures' note-taking such as illustrative diagrams and outlines on post-test performance (Bui \& McDaniel, 2015).

Critical thinking assists learners to ameliorate problems or make essential evaluations by using their prior knowledge (Lynch, 2006). Leaners should be encouraged to be critical thinkers while learning through searching for meaning, struggling with ideas and using logic in arguments (Karbalaei, 2012). Fahim, Barjesteh and Vaseghi (2012) suggested that critical thinking activities used in the classroom can help students "stay with" or "go beyond" the presented information. Hohmann and Grillo (2014) designed a critical thinking rubric program to evaluate and strengthen students' use of critical thinking skills. The researchers found that the repeated use of these rubrics with the students contributed to increasing course grades. Likewise, the positive effects of critical thinking on academic achievement have been shown by researchers (e.g., Afshar \& Movassagh, 2014; Alrubaei, 2009; Ayub, 2014; Mall-Amiri \& Sheikhy, 2014; Stewart, 2000).

One of the affective variables that gained popularity among scholars and educators and was proved to significantly affect academic achievement is motivation. The self-determination theory has differentiated between different types of motivation. Based on Deci and Ryan (2008), motivation basically can be divided into autonomous and controlled motivation. Autonomous motivation consists of intrinsic motivation and a sort of extrinsic motivation in which people perceive the task's value and "ideally" integrate it in their "sense of self". On the other hand, controlled motivation involves external regulation, in which one's action is the result of rewards and punishment, and introjected motivation, in which motivation is "partially internalized" and empowered by factors such as self-esteem, approval, or avoiding shame. In this study, the focus is on two clearly defined types of motivations: intrinsic and extrinsic motivation. Simply, intrinsic motivation is about doing something for its own sake; while extrinsic motivation entails doing something to gain something else (Santrock, 2009). Intrinsically motivated students believe on the value of learning for seeking knowledge, whereas, extrinsically motivated learners seek learning to attain external goals such as gaining grades or pleasing others (Lynch, 2006). Motivation can influence students' engagement inside the classroom since learners with high motivation may feel bored if the learning process is very slow and low-motivated learners may face difficulties to cope with fast learning process (Yusri et al., 2013). It was found that intrinsic motivation pushes learners towards using multiple learning resources and higher order learning strategies (Yusri et al., 2013). Also, intrinsic motivation, but not extrinsic motivation, was reported to significantly predict course grades of students (e.g., Areepattamannil, 2014b; Lepper, Corpus, \& Iyengar, 2005; Lynch, 2006).

Another affective variables that can crucially affect learning, generally, and academic achievement, particularly, is anxiety. Anxiety is "the worry that the students may experience" in a specific task, a subject or a test (Wolters et al., 2014, p. 505). Anxious students could be less likely to perform well at school. Anxiety was found negatively correlated with students' expectations of success (Virtanen, Nevgi, \& Niemi, 2015). Moreover, Sideridis (2008) found that mastery avoidance goal orientation was associated with anxiety. Many other researchers have pinpointed to the negative impact that anxiety leaves on students' academic achievement (e.g., Puteh \& Khalin, 2016; Rana \& Mahmood, 2010; Singh \& Thukral, 2009; Zusho et al., 2003).

While some studies have examined the effect of affective variables and cognitive processes on academic achievement separately (e.g., Areepattamannil \& Caleon, 2013; Mahyuddin et al., 2006; Steinmayr \& Spinath, 2009; Strang, 2014), there are only few studies that investigated the competing effects of both cognitive and affective aspects of learning. One example of those studies is Ygzaw and Fentie (2013) who found that unlike motivational beliefs and metacognitive processes, cognitive processes (rehearsal, elaboration, and organization) used by the students were the only significant predictors of reading performance. Consistently, similar results were reported by other researchers (e.g., Gagne' \& Pe`re, 2001). In contrast, Zusho et al. (2003) found that motivational constructs of task value and self-efficacy beliefs were better predictors of final performance than cognitive processes. Other researchers have also supported the surpassing role of motivational constructs over some information processing or cognitive processes (e.g., Albaili, 1997). However, Spinath, Harlaar and Plomin 
(2006) indicated that general mental ability (i.e., cognitive factors) was the only predictor of academic achievement in science; but, ability self-perception and intrinsic value (i.e., affective factor) were the strongest predictors, beyond general mental ability, in mathematics and English.

Whereas those studies examined the competing effects of cognitive processes verses affective variables, some studies have looked at the various effects on achievement within each set of variables. To illustrate, affective variables (i.e, extrinsic motivation, intrinsic motivation, anxiety) and cognitive processes (memorization, critical thinking, organization) may differently influence academic achievement when differences within each model are examined. Despite the lack of research, to the researchers' knowledge, that focused on this scope, some few studies were documented in the literature. For example, with regard to affective variables, Lynch (2006) found that unlike extrinsic motivation, intrinsic motivation was associated with course grades. In addition, according to Hayenga and Corpus (2010), students who have low-extrinsic motivation coupled with high intrinsic motivation got higher grades than students in two other clusters (i.e., students with low levels of both extrinsic and intrinsic motivation, and students with high levels of both extrinsic and intrinsic motivation). Despite the high quantity the students had of both types of motivations, it is considered as a poor quality motivation. Thus, the "ratio of intrinsic to extrinsic motivation" is a stronger predictor of academic achievement than the amount of motivation the students have. However, the researchers couldn't find any study that compared between the role of motivation in contrast to anxiety (as two affective factors) in predicting academic achievement.

Regarding cognitive processes, although many studies have examined the frequencies of each type of processes used by students (e.g., Ghafournia, 2014; Riazi \& Rahimi, 2005; Srisupha, 2012), very few research, according to the researchers' knowledge, compared how each process differs in its effects on achievement or which process is a stronger predictor of achievement.

Another important area of research is the examination of cross-cultural differences according to which the role of cognitive processes and affective variables on academic achievement varies. For example, Areepattamannil and Caleon (2013) examined the relationship between two cognitive processes, memorization and elaboration, and mathematics achievement across four East Asian educational systems: Singapore, Korea, Shanghai-China and Hong Kong-China. The findings presented that memorization was negatively associated with academic achievement in all educational systems. However, elaboration processes were not associated with mathematics achievement in Shanghai-China and Korea; and they were negatively linked to mathematics achievement in Hong Kong-China and Singapore. Similar results were found by the same researcher, Areepattamannil (2014a), in which students' self-reported use of memorization and elaboration demonstrated various relationships (i.e., positive, negative or no relationship) on students' course grades across two Indian states: Tamil Nadu and Himachal Pradesh.

In brief, this study will add to the literature by examining not only the competing role of cognitive processes verses affective variables, but also it examines the competing role of each process/variable within each set of factors (cognitive and affective). In addition to the lack of studies conducted to examine these two areas of interest, little research, if any, has been done in the Omani context to compare the predictive role of cognitive processes and affective variables in predicting students' academic achievement. Therefore, this study examines Omani students' perceptions of their usage of cognitive processes (i.e., memorization, organization and critical thinking) and affective variables (i.e., extrinsic and intrinsic motivation, and anxiety) and their prediction role of academic achievement.

\section{Methodology}

\subsection{The Sample}

The sample of the current study consisted of 342 students from different school districts in the Sultanate of Oman. Female students represented $74.6 \%$ of the total sample. Students were in grades 5 to 11 of public schools and their ages ranged from 10 to $19(M=14.22, S D=1.73)$. Students' grade average point (GPA) ranged from 50 to $95(M=75.87, S D=14.04)$. The students came from families where $75 \%$ of mothers and $56.5 \%$ of fathers having less than secondary school certificate. The participants responded to the questionnaires during class session. Permission to collect data was obtained from the districts' administrations and then from schools' administrations. Students were assured confidentiality and they were granted the option to participate in the study or not. All students attended classes during data collection chose to participate.

\subsection{Measures}

The participants responded to a group of existing measures as a part of a national study examining different learning variables. For the use of the current study, the participants' data in six measures were reported in 
addition to their grade average point (GPA) using their reported grade. The first measures examined students' use of critical thinking strategies and consisted of 4 items $(\alpha=0.48)$. The second measure consisted of 5 items and examined students' organizational strategies $(\alpha=0.46)$. The third measure dealt with students' use of memorization strategies and included 6 items $(\alpha=0.48)$. For the affective model, the participants responded to three questionnaires examining their levels of intrinsic motivation ( 5 items, $\alpha=0.53$ ), extrinsic motivation (6 items, $\alpha=0.45$ ), and anxiety levels ( 5 items, $\alpha=0.58$ ). All measures used a 5 -point Likert scale that ranged from strongly agree (5) to strongly disagree (1). More validity and reliability indicators for the measures when used with Omani students are reported somewhere else (Aldhafri et al., 2015; Aldhafri et al., 2012).

\section{Results}

Data were screened for outliers and no threats were identified. Descriptive analyses of the main variables of the study showed that the participants have high levels of using the affective variables (i.e., intrinsic motivation, extrinsic motivation, anxiety) and high levels of using the cognitive variables (i.e., memorization, organization, critical thinking). The participants also showed high mean score of GPA.

To examine the predictive role of the two competing models in predicting students' academic achievement, two separate regression models were used. In the first model of predicting students' academic achievement, the affective variables (i.e., intrinsic motivation, extrinsic motivation, anxiety) were used as predictors. In the second model, the cognitive variables (i.e., memorization, organization, critical thinking) were used to predict students' academic achievement.

As it can be seen in Table 1, the results of the first regression model show that two affective variables were significant predictors of students' academic achievement. The model indicates that students' intrinsic motivation $(t=2.14, p<0.05)$ and their anxiety level $(t=-3.79, p<0.001)$ significantly predicted their academic achievement. This affective model, however, explained only $5.4 \%$ of variance in the independent variable, students' academic achievement.

Table 1. Results of the multiple regression models to predict students' academic achievement

\begin{tabular}{|c|c|c|c|c|c|c|}
\hline Model & $\boldsymbol{B}$ & S.E & $\boldsymbol{\beta}$ & $t$ & sig & $R^{2}$ \\
\hline \multicolumn{7}{|l|}{ Affective Model } \\
\hline Constant & 94.56 & 7.54 & & 12.45 & 0.000 & \\
\hline Test Anxiety & -7.64 & 2.01 & -0.02 & -3.79 & 0.000 & \\
\hline Extrinsic Motivation & -2.89 & 2.33 & -0.07 & -1.24 & 0.215 & 0.054 \\
\hline Intrinsic Motivation & 4.34 & 2.02 & 0.13 & 2.14 & 0.032 & \\
\hline \multicolumn{7}{|l|}{ Affective Model } \\
\hline Constant & 104.83 & 6.76 & & 15.49 & 0.00 & \\
\hline Organization & 1.84 & 1.78 & 0.06 & 1.03 & 0.30 & \\
\hline Memorization & 2.90 & 1.91 & 0.09 & 1.51 & 0.13 & 0.073 \\
\hline Critical Thinking & 8.17 & 2.06 & 0.24 & 3.96 & 0.00 & \\
\hline \multicolumn{7}{|c|}{ Affective \& Cognitive Models } \\
\hline Constant & 104.45 & 7.71 & & 13.54 & 0.000 & \\
\hline Test Anxiety & -4.61 & 2.16 & -0.13 & -2.13 & 0.033 & \\
\hline Extrinsic Motivation & -1.11 & 2.34 & -0.03 & -0.47 & 0.636 & \\
\hline Intrinsic Motivation & 6.51 & 2.12 & 0.20 & 3.06 & 0.002 & \\
\hline Organization & 1.29 & 1.93 & 0.04 & 0.67 & 0.503 & \\
\hline Memorization & 3.76 & 1.93 & 0.12 & 1.94 & 0.053 & 0.110 \\
\hline Critical Thinking & 7.74 & 2.18 & 0.22 & 3.54 & 0.000 & \\
\hline
\end{tabular}


In the second regression model, the results show that only one cognitive variable significantly predicted students' academic achievement. The model demonstrates that students' critical thinking was the only predictor of their academic achievement $(t=3.96, p<0.001)$. This cognitive model explained $7.3 \%$ of variance in students' academic achievement.

The results from the second regression model show that the cognitive model is stronger than the affective model in predicting students' academic achievement. However, the two models together (see Model 3 in Table 1) explained only $11 \%$ of variance in students' academic achievement.

\section{Discussion}

The current study aimed to examine the possible relationship between a group of affective and cognitive variables and students' academic achievement. Specifically, the researchers investigated the competing effects of the affective model compared to the cognitive model in predicting the levels of students' academic achievement using underrepresented sample of Arab students from the Sultanate of Oman.

The results presented that only some cognitive and some affective variables were significant predictors of students' academic achievement. Within the affective model, students' intrinsic motivation and their anxiety levels, but not their extrinsic motivation, were significant predictors of their academic achievement. This supports the importance of promoting students' intrinsic motivation as a significant factor affecting students' academic achievement. Model learning theories such as self-determination emphasizes the core role of intrinsic motivation in influencing students' learning (e.g., Deci \& Ryan, 2008). As supported by previous studies, intrinsic motivation can predict course grades (e.g., Lepper et al., 2005; Lynch, 2006); also, it pushes students' toward using higher order learning resources and strategies (Yusri et al., 2013). In addition, the results show that it is important to control the levels of students' anxiety and work to minimize it as much as possible considering its negative effects on students' academic achievement. The findings of the current study suggested that students' anxiety level is a possible threat to their academic achievement. Past research stresses that high level of anxiety is most likely to undermine their ability to achieve well in their schoolwork (Puteh \& Khalin, 2016; Rana \& Mahmood, 2010; Singh \& Thukral, 2009). The effects of this affective model were limited looking at the percentage of variance in students' academic achievement accounted for by this model. In addition, the results show that extrinsic motivation was not a significant predictor of students' academic achievement in the presence of the other two affective variables (i.e., intrinsic motivation and anxiety level). This result is consistent with other studies which found that extrinsic motivation is less effective on students' achievement compared with intrinsic motivation (e.g., Areepattamannil, 2014b; Lemos \& Veríssimo, 2014; Lin, McKeachie, \& Kim, 2003).

The cognitive model was a significant predictor of students' academic achievement. The effect of this model, however, was limited to the significant effect of students' critical thinking on their academic achievement. The other two cognitive variables were not significant predictors (i.e., organization and memorization) when examined along with students' critical thinking. Recent research of critical thinking shows the importance of training students to develop different critical thinking strategies considering the cumulative evidence of their positive effects on increasing students' academic achievement (e.g., Afshar \& Movassagh, 2014; Alrubaei, 2009; Ayub, 2014; Mall-Amiri \& Sheikhy, 2014; Stewart, 2000). The cognitive model, however, did not explain large percentage of variance in students' academic achievement.

The results of the current study suggest that there are other important variables that may influence students' academic achievement. When the two models were examined together in the same regression model (see Model 3 in Table 1), the two models only explained $11 \%$ of variance in students' academic achievement. Future research may examine other important variables within the Omani school context such as students' self-efficacy beliefs (Aldhafri, 2016) and social goals (King, McInerney, \& Watkins, 2012, 2013; King \& Watkins, 2012) as self-related variables or classroom climate and students' perceptions of parenting styles as context-related variables.

\section{Acknowledgements}

This research was thankfully supported by a grant (RC/EDU/PSYC/12/01) from The Research Council in Oman. This funding source had no involvement in the conduct of the research and preparation of the article. 


\section{References}

Afshar, H. S., \& Movassagh, H. (2014). On the relationship among critical thinking, language learning strategy use and university achievement of Iranian English as a foreign language majors. Language Learning Journal, 1-17. http://dx.doi.org/10.1080/09571736.2014.914238

Albaili, M. (1997). Differences among low-, average- and high-achieving college students on learning and study strategies. Educational Psychology: An International Journal of Experimental Educational Psychology, 17(1-2), 171-177. http://dx.doi.org/10.1080/09571736.2014.914238

Aldhafri, S. (2016). Theoretical and psychometric review of Arabic teachers' self-efficacy beliefs research. In R. B. King, \& A. B. Bernardo (Eds.), the Psychology of Asian Learners (pp. 139-155). Singapore: Springer Singapore. http://dx.doi.org/10.1007/978-981-287-576-1_9

Aldhafri, S., \& Alkharusi, H., \& Al Ismaili, A. (2015). Predicting English test anxiety: How memorization and critical thinking function? Theory and Practice in Language Studies, 5(6), 1159-1165. http://dx.doi.org/10.17507/tpls.0506.05

Aldhafri, H., Neisler, O., Al-Barwani, T., Clayton, D., Al-Sulaimani, H., Khan, M. A., ... Al-Kalbani, M. (2012). Psychometric properties of the Motivated Strategies for Learning Questionnaire for Sultan Qaboos University students. College Student Journal, 46(3), 567-580.

Alrubaei, A. (2009). Altafkeer Alnaqid wa elaqatuh be altahseel Aldirasi lada talabat kuliat altarbia, jamiat Alhadidah [Critical thinking and its relation to academic achievement among college of education students, Alhadidah University]. Psychology, 30-51.

Ansarin, A. A., Zohrabi, M., \& Zeynali, S. (2012). Language learning strategies and vocabulary size of Iranian EFL learners. Theory and Practice in Language Studies, 2(9), 1841. http://dx.doi.org/10.4304/tpls.2.9.1841-1848

Areepattamannil, S., \& Caleon, I. (2013). Relationships of cognitive and metacognitive learning strategies to mathematics achievement in four high-performing east Asian education systems. The Journal of Genetic Psychology, 174(6), 696-702. http://dx.doi.org/10.1080/00221325.2013.799057

Areepattamannil, S. (2014a). Are learning strategies linked to academic performance among adolescents in two states in India? A Tobit regression analysis. The Journal of General Psychology, 141(4), 408-424. http://dx.doi.org/10.1080/00221309.2014.957637

Areepattamannil, S. (2014b). Relationship between academic motivation and mathematics achievement among Indian adolescents in Canada and India. The Journal of General Psychology, 141(3), $247-262$. http://dx.doi.org/10.1080/00221309.2014.897929

Ayub, H. (2014). Elaqat Altafkeer Alnaqid bemaharat Hal Almushkilat wa altahseel Aldirasi letalbat Jamiat Alimam Muhamud bin Saud Alislamia [The relationship between critical thinking, problem solving skill and academic achievement among students of AL-Imam Muhammed bin Saud Islamic School]. Journal of Educational Sciences, 3(2), 382-383.

Beaujean, A., Firmin, M., Attai, S., Johnson, C., Firmin, R., \& Mena, K. E. (2011). Using personality and cognitive ability to predict academic achievement in a young adult sample. Personality and Individual Differences, 51(6), 709-714. http://dx.doi.org/10.1016/j.paid.2011.06.023

Berg, G., \& Coetzee, L. (2014). Academic self-concept and motivation as predictors of academic achievement. International Journal of Educational Sciences, 6(3), 469-478.

Bipp, T., \& Dam, K. (2014). Extending hierarchical achievement motivation models: The role of motivational needs for achievement goals and academic performance. Personality and individual differences, 64, 157-162. http://dx.doi.org/10.1016/j.paid.2014.02.039

Bui, D., \& McDaniel, M. (2015). Enhancing learning during lecture note-taking using outlines and illustrative diagrams. Journal of Applied Research in Memory and Cognition, 4, 129-135. http://dx.doi.org/10.1016/j.jarmac.2015.03.002

Ghafournia, N. (2014). Language learning strategy use and reading achievement. English Language Teaching, 7(4), 64-73. http://dx.doi.org/10.5539/elt.v7n4p64

Chu, Y., Huang, B., Shih, M., \& Tsai, C. (2012). A look at EFL technical students' use of learning strategies in Taiwan. World Journal of Education, 2(3), 16-24. http://dx.doi.org/10.5430/wje.v2n3p16 
Danili, E., \& Reid, N. (2006). Cognitive factors that can potentially affect pupils' test performance. Chemistry Education Research and Practice, 7(2), 64-83. http://dx.doi.org/10.1039/B5RP90016F

Deci, E., \& Ryan, R. (2008). Self-determination theory: A macrotheory of human motivation, development and health. Canadian Psychology, 49(3), 182-185. http://dx.doi.org/10.1037/a0012801

Djemil, A. (2010). Effect of memorization of the multiplication tables on students' performance in high school (doctoral dissertation). Available from ProQuest Dissertation and Thesis (UMI No. 3397766).

Fahim, M., Barjesteh, H., \& Vaseghi, R. (2012, 2011). Effects of critical thinking strategy training on male/female EFL learners' reading comprehension. English Language Teaching, 5(1), 140-145. http://dx.doi.org/10.5539/elt.v5n1p140

Froiland, J., \& Oros, E. (2014). Intrinsic motivation, perceived competence and classroom engagement as longitudinal predictors of adolescent reading achievement. Educational Psychology: An International Journal of Experimental Educational Psychology, 34(2), 119-132, http://dx.doi.org/10.1080/01443410.2013.822964

Gagne, F., \& Pere, F. S. (2001). When is IQ controlled, does motivation still predict achievement? Intelligence, 30(1), 71-100. http://dx.doi.org/10.1016/S0160-2896(01)00068-X

Ghafournia, N. (2014). Language learning strategy use and reading achievement. English Language Teaching, 7(4), 64-73. http://dx.doi.org/10.5539/elt.v7n4p64

Hayenga, A., \& Corpus, J. (2010). Profiles of intrinsic and extrinsic motivations: A person-centered approach to motivation and achievement in middle school. Motivation and Emotion, 34, 371-383. http://dx.doi.org/10.1007/s11031-010-9181-x

Hohmann, J., \& Grillo, M. (2014). Using critical thinking rubrics to increase academic performance. Journal of College Reading and Learning, 45, 35-51. http://dx.doi.org/10.1080/10790195.2014.949551

Ju, S., Zhang, D., \& Katsiyannis, A. (2012). The causal relationship between academic self-concept and academic achievement for students with learning disabilities: An analysis of SEELS data. Journal of Disability Policy Studies, 24(1), 4-114. http://dx.doi.org/10.1177/1044207311427727

Karbalaei, A. (2012). Critical thinking and academic achievement. Íkala, Revista De Lenguaje y Cultura, 17(2), $121-128$.

Keng, H. (1996). A comparative study of note-taking, outlining and concept mapping learning strategies on national Taipei teachers college students' understanding of heat and temperature (doctoral dissertation). Available from ProQuest Dissertation and Thesis Database (UMI No. 9629675).

King, R., McInerney, D., \& Watkins, D. (2012). Studying for the sake of others: The role of social goals on academic engagement. Educational Psychology: An International Journal of Experimental Educational Psychology, 32(6), 749-776. http://dx.doi.org/10.1080/01443410.2012.730479

King, R., McInerney, D., \& Watkins, D. (2013). Examining the role of social goals in school: A study in two collectivist cultures. European Journal of Psychology of Education, 28(4), 1505-1523. http://dx.doi.org/10.1007/s10212-013-0179-0

King, R., \& Watkins, D. (2012). "Socializing” achievement goal theory: The need for social goals. Psychological Studies, 57(1), 112-116. http://dx.doi.org/10.1007/s12646-011-0140-8

Lee, C. (2010). An overview of language learning strategies. ARECLS, 7, 132-152.

Lemos, M., \& Veríssimo, L. (2014). The relationships between intrinsic motivation, extrinsic motivation, and achievement, along elementary school. Procedia-Social and Behavioral Sciences, 112, 930-938. http://dx.doi.org/10.1016/j.sbspro.2014.01.1251

Lepper, M., Corpus, J., \& Iyengar, S. (2005). Intrinsic and extrinsic motivational orientations in the classroom: Age differences and academic correlates. Journal of Educational Psychology, 97(2), 184-196. http://dx.doi.org/10.1037/0022-0663.97.2.184

Levpušček, M., \& Zupanc`ič ${ }^{`}$, M. ( 2009). Math achievement in early adolescence the role of parental involvement, teachers' behavior, and students' motivational beliefs about math. Journal of Early Adolescence, 29(4), 541-570. http://dx.doi.org/10.1177/0272431608324189

Lin, Y., McKeachie, W., \& Kim, Y. (2003). College student intrinsic and/or extrinsic motivation and learning. Learning and Individual Differences, 13, 251-258. http://dx.doi.org/10.1016/S1041-6080(02)00092-4 
Little, T., Das, J., Carlson, J., \& Yachimowicz, D. (1993). The role of higher-order cognitive abilities as mediators of deficits in academic performance. Learning and Individual Differences, 5(3), 219-240. http://dx.doi.org/10.1016/1041-6080(93)90004-C

Lynch, D. (2006). Motivational factors, learning strategies and resource management as predictors of course grades. College Student Journal, 40(2), 423-482.

Mahyuddin, R., Elias, H., Cheong, L., Muhamad, M., Noordin, N., \& Abdullah, M. (2006). The relationship between students' self-efficacy and their English language achievement. Jurnal Pendidik dan Pendidikan, 21, 61-71.

Mall-Amiri, B., \& Sheikhy, F. (2014). The comparative impact of autonomy and critical thinking on EFL learners' writing achievement. Theories and Practice in Language Studies, 14(5), 903-916. http://dx.doi.org/10.4304/tpls.4.5.903-916

Marsh, H. (2004). Negative effects of school-average achievement on academic self-concept: A comparison of big-fish-little bond effect across Australian states and territories. Australian Journal of Education, 48(1), 5-26. http://dx.doi.org/10.1177/000494410404800102

Matovu, M. (2014). A structural equation modelling of the academic self-concept scale. International Electronic Journal of Elementary Education, 6(2), 185-198.

Mouziraji, A., \& Mouziraji, A. (2015). Memorization makes progress. Theory and Practice in Language Studies, 5(4), 870. http://dx.doi.org/10.17507/tpls.0504.25

Oxford, R. (1990). Language learning strategies: What every teacher should know. Boston: Heinle \& Heinle Publishers.

Pintrich, P. R. (2004). A conceptual framework for assessing motivation and self-regulated learning in college students. Educational Psychology Review, 16(4), 385-407. http://dx.doi.org/10.1007/s10648-004-0006-x

Pinxten, M., Fraine, B., Damme, J., \& D’Haenens, E. (2013). Student achievement and academic self-concept among secondary students in Flanders: Gender and changes over time. Irish Educational Studies, 32(2), 157-178. http://dx.doi.org/10.1080/03323315.2012.749058

Puteh, M., \& Khalin, S. (2016). Mathematics anxiety and its relationship with the achievement of secondary students in Malaysia. International Journal of Social Science and Humanity, 6(2), 191-122. http://dx.doi.org/10.7763/IJSSH.2016.V6.630

Rana, R., \& Mahmood, N. (2010). The relationship between test anxiety and academic achievement. Bulletin of Education and Research, 32(2), 63-74.

Rayan, R., \& Deci, E. (2000). Intrinsic and extrinsic motivations: Classic definitions and new directions. Contemporary Educational Psychology, 25, 54-67. http://dx.doi.org/10.1006/ceps.1999.1020

Retelsdorf, J., Köller, O., \& Möller, J. (2014). Reading achievement and reading self-concept-testing the reciprocal effects model. Learning and Instruction, 29, 21-30. http://dx.doi.org/10.1016/j.learninstruc.2013.07.004

Riazi, A., Rahimi, M. (2005). Iranian EFL learners' pattern of language learning strategy use. The Journal of Asia TEFL, 2(1), 103-129.

Roskam, I., \& Nils, F. (2007). Predicting intra-individual academic achievement trajectories of adolescents nested in class environment: Influence of motivation, implicit theory of intelligence, self-esteem and parenting. Psychologica Belgica, 47(1-2), 119-143. http://dx.doi.org/10.5334/pb-47-1-119

Santrock, J. (2009). Educational Psychology: A tool for effective teaching (4th ed.). New York: McGraw-Hill.

Seaton, M., Parker, P., Marsh, H., Craven, R., \& Yeung, A. (2014). The reciprocal relations between self-concept, motivation and achievement: Juxtaposing academic self-concept and achievement goal orientations for mathematics success. Educational Psychology: An International Journal of Experimental Educational Psychology, 34(1), 49-72. http://dx.doi.org/10.1080/01443410.2013.825232

Shiffrin, R., \& Steyvers, M. (1997). A model for recognition memory: REM-retrieving effectively from memory. Pshychonomic Bulletin and Review, 4(2), 145-166. http://dx.doi.org/10.3758/BF03209391

Sideridis, G. D. (2008). The regulation of affect, anxiety, and stressful arousal from adopting mastery-avoidance goal orientations. Stress and Health, 24(1), 55-69. http://dx.doi.org/10.1002/smi.1160 
Singh, S., \& Thukral, P. (2009). The role of anxiety in achievement. Journal of Exercise Science and Physiotherapy, 5(2), 122-125.

Singh, K., Granville, M., \& Dika, S. (2002). Mathematics and science achievement: Effects of motivation, interest, and academic engagement. The Journal of Educational Research, 95(6), 323-332, http://dx.doi.org/10.1080/00220670209596607

Spinath, B., Spinath, F., Harlaar, N., \& Plomin, R. (2006). Predicting school achievement from general cognitive ability, self-perceived ability, and intrinsic value. Intelligence, 34, 363-374. http://dx.doi.org/10.1016/j.intell.2005.11.004

Srisupha, R. (2012). Thai students language learning strategies. Quarterly Journal of Chinese Studies, 2(2), 53-67.

Steinmayr, R., \& Spinath, B. (2009). The importance of motivation as a predictor of school achievement. Learning and Individual Differences, 19, 80-90. http://dx.doi.org/10.1016/j.lindif.2008.05.004

Stewart, P. (2000). The Role of Psychological Type and Critical Thinking in Doctoral Student Achievement (doctoral thesis). Available from ProQuest Dissertation and Theses database (UMI No. 3004948).

Strang, K. D. (2014). Cognitive learning strategy as a partial effect on major field test in business results. Journal of Education for Business, 89(3), 142-148. http://dx.doi.org/10.1080/08832323.2013.781988

Ting, K., \& Chao, M. (2013). The application of self-regulated strategies to blended learning. English Language Teaching, 6(7), 26-32. http://dx.doi.org/10.5539/elt.v6n7p26

Yigzaw, A., \& Fentie, A. (2013). The impact of students' self-regulated language learning on their reading achievement in Ethiopian high schools: Grade 9 in focus. Journal of Media and Communication Studies, $5(5), 44-51$.

Yu, X. (2010). Text memorization in china: Hearing the learner and teacher voice (doctoral thesis). University of $\begin{array}{lllll}\text { Southampton. } & \text { Retrieved } & \text { September } & 21 & \text { 2015, from }\end{array}$ http://search.proquest.com/docview/1033191915?pq-origsite=summon

Yusri, G., Rahimi, N., Shah, P., \& Wah, W. (2013). Cognitive and metacognitive learning strategies among Arabic language students. Interactive Learning Environments, 21(3), 290-300. http://dx.doi.org/10.1080/10494820.2011.555840

Virtanen, P., Nevgi, A., \& Niemi, H. (2015). Self-regulation in higher education: Students' motivational, regulational and learning strategies, and their relationships to study success. Studies for the Learning Society, 3(1-2), 20. http://dx.doi.org/10.2478/sls-2013-0004

Wolters, C., Denton, C., York, M., \& Frances, D. (2014). Adolescents' motivation for reading: Group differences and relation to standardized achievement. Reading and Writing, 27, 503-533. http://dx.doi.org/10.1007/s11145-013-9454-3

Zusho, A., Pintrich, P., \& Coppola, B. (2003). Skill and will: The role of motivation and cognition in the learning of college chemistry. International Journal of Science Education, 25(9), 1081-1094. http://dx.doi.org/10.1080/0950069032000052207

\section{Copyrights}

Copyright for this article is retained by the author(s), with first publication rights granted to the journal.

This is an open-access article distributed under the terms and conditions of the Creative Commons Attribution license (http://creativecommons.org/licenses/by/4.0/). 